\title{
molecules
}

ISSN 1420-3049

www.mdpi.com/journal/molecules

Article

\section{$\mathbf{P d}^{0}$-Catalyzed Methyl Transfer on Nucleosides and Oligonucleotides, Envisaged as a PET Tracer}

\author{
Damien James ${ }^{1}$, Jean-Marc Escudier ${ }^{2}$, Magali Szlosek-Pinaud ${ }^{1, *}$ and Eric Fouquet ${ }^{1, *}$ \\ 1 Institut des Sciences Moléculaires, Université de Bordeaux, UMR5255, 351 Cours de la Libération, \\ Talence 33405, France; E-Mail: d.james@u-bordeaux1.fr \\ 2 Laboratoire de Synthèse et Physicochimie- de Molécules d'Intérêt Biologique, \\ Université Paul Sabatier, UMR5068, 118 route de Narbonne, Toulouse 31062, France; \\ E-Mail: escudier@chimie.ups-tlse.fr
}

* Authors to whom correspondence should be addressed; E-Mails: m.szlosek@ism.u-bordeaux1.fr (M.S.-P.); e.fouquet@ism.ubordeaux1.fr (E.F.); Tel.: +33-540-002-829 (E.F.);

Fax: +33-540-006-386 (M.S.-P. \& E.F.).

Received: 26 August 2013; in revised form: 14 October 2013 / Accepted: 23 October 2013 /

Published: 5 November 2013

\begin{abstract}
The methyl transfer reaction from activated monomethyltin, via a modified Stille coupling reaction, was studied under "ligandless" conditions on fully deprotected 5 '-modified nucleosides and one dinucleotide. The reaction was optimized to proceed in a few minutes and quantitative yield, even under dilute conditions, thus affording a rapid and efficient new method for oligonucleotide labelling with carbon-11.
\end{abstract}

Keywords: Stille coupling; nucleosides; oligonucleotides; methyl transfer; Positron Emission Tomography

\section{Introduction}

Coupling reactions mediated by transition metal catalysis are particularly powerful methods for the creation of carbon-carbon bonds. These reactions are especially recognized for combination of the mildness of the reaction conditions and their high efficiency and selectivity. Among them, palladium is undoubtedly the metal of choice and has been extensively used in the past decades in applications ranging from organic methodology development to total synthesis of complex structures. In recent years the field of applications has extended to the functionalization of biomolecules, mainly due to the 
ability of these coupling reactions to procede without any protection/deprotection sequences. In that context Positron Emission Tomography (PET) represents a field of choice for the application of the original palladium-catalysed coupling reactions. Indeed, PET is a powerful imaging technique for clinical, medical and biological investigations in various areas such as oncology, cardiology, and neurosciences, as well as for drug development. Due to the increasing need of this technique in in vivo biochemistry and medicine, the development of new tracers and radiolabelling strategies is always in demand [1-3], as outlined in recent reviews for the two most commonly used short half-life radioisotopes, e.g., carbon-11 $\left(t_{1 / 2}=20.4 \mathrm{~min}\right)$ [4] and fluorine-18 ( $\left.t_{1 / 2}=109.6 \mathrm{~min}\right)$ [5,6]. As a consequence, simple and rapid synthetic processes including organic transformations and purifications are required. Importantly, such a strategy becomes even more challenging when the biomolecule used as substrate is available in very low quantity, as the coupling reaction has to meet four mandatory constraints: (i) the selectivity of the reaction which is imposed by the presence of several functionalities and the absence of protecting groups, (ii) the mildness of the conditions required by the fragility of most of the substrates, (iii) the rapidity of the reaction which is directly related to the short half-live of the isotopes, especially for carbon-11, and finally (iv) the efficiency of the reaction which may have to occur under extremely dilute conditions either of the radiotracer and/or the biomolecule to be labeled.

In recent years, an increase of the use of palladium-mediated reactions for labeling purposes was observed [7]. Among these reactions, the palladium-mediated Stille reaction has proved to be an important route for the synthesis of PET radiotracers [8-10]. At this point, it is essential to note that most of the restrictions encountered in pharmaceutical industry, when using organotins for the synthesis of bioactive molecules, are not a problem anymore when applied to radiochemistry. Thus the palladium-catalysed Stille coupling still remains a topical reaction for the synthesis of radiotracers. It usually involves the reaction of $\left[{ }^{11} \mathrm{C}\right]$-methyliodide with an aryl triorganostannane leading to a ${ }^{11} \mathrm{C}$-carbon-carbon coupled product. However, the preparation of an organostannyl precursor is not always straightforward, and in the case of functionalized organostannanes, nucleophilic groups have to be protected in order to prevent methylation as a side reaction [11]. Finally, difficulties might be encountered in separating the tracer from triorganotin residues.

Recently, we have described a new ${ }^{11} \mathrm{C}$-labeling methodology based on the transfer reaction of the $\left[{ }^{11} \mathrm{C}\right]$ methyl group, from the ${ }^{11} \mathrm{C}$-labeled hypervalent methylstannate, first onto simple aryl halides [12] and then onto polyfunctional and heteroaromatic tracers for central nervous system [13]. Although the preparation of the labeled methyltin reagent is made from $\left[{ }^{11} \mathrm{C}\right]$-methyl iodide, this new approach offers several advantages such as the ligand-free conditions and the formation of a nontoxic and easily removable inorganic tin by-product [14]. Our next interest was to investigate the applicability of this methodology for the labelling of important biomolecules such as nucleosides and oligonucleotides [15] which present an additional challenge in terms of available quantities (which are often tiny due to the costly and time consuming process for their synthesis), limiting until now the usefulness and expansion of such radiotracer. As a first approach, the study of the feasibility of the cross-coupling reaction under rapid and dilute conditions, on unprotected nucleosidic and dinucleotidic substrates bearing an iodoaryl moiety at the 5' position, with unlabelled methyl iodide is described herein (Scheme 1). 
Scheme 1. Methyl transfer reaction.

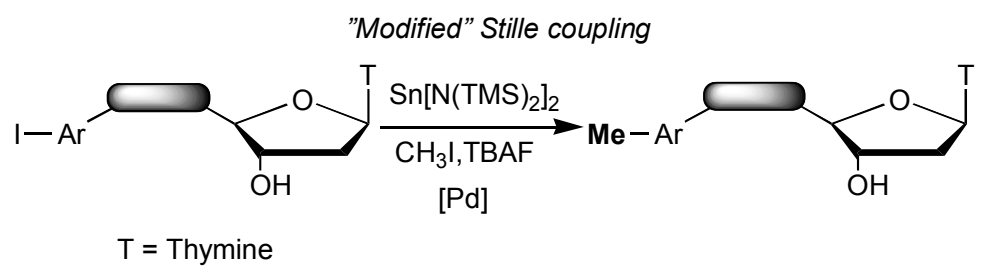

\section{Results and Discussion}

Starting from thymidine aldehyde, we have synthesized 5'C-substituted thymidine derivatives either with alkyne or azide groups and then engaged them into a conjugation reaction with iodoaryl moieties by "click chemistry" leading to compounds 1a-c (Figure 1) [16]. They were then used as substrates for the methyl transfer study. The monomethyltin reagent was prepared from iodomethane and Lappert's stannylene $[17,18]\left(\mathrm{Sn}\left[\mathrm{N}(\mathrm{TMS})_{2}\right]_{2}\right)$ and activated in situ with TBAF (tetrabutylammonium fluoride) giving the corresponding methylstannate, according to the previously described procedure [12].

Figure 1. Substrates for the methyl transfer study.
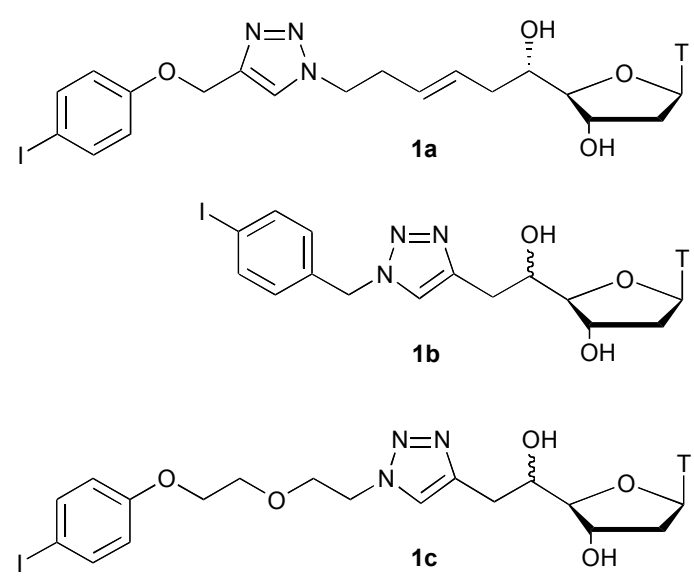

Previous results led us run the reaction at $100{ }^{\circ} \mathrm{C}$, using tris-(dibenzylideneacetone)dipalladium as catalyst $\left(\mathrm{Pd}_{2} \mathrm{dba}_{3}, 10 \mathrm{~mol} \%\right)$ under so-called "ligand free" conditions. Furthermore, due to the solubility properties of the substrates, the palladium-catalysed cross-coupling reaction was studied first in DMF instead of dioxane. In order to minimize reaction times and optimize the reaction yields, the concentration of the substrate was varied and the addition of CuI was studied (Table 1). Initially, the reaction was done using $1 \mathbf{a}(0.2 \mathrm{M})$ as substrate without $\mathrm{CuI}$ (entry 1$)$. In this case, a total conversion was observed in 5 min leading to the desired product 2a, along with some degradation estimated to be about $20 \%$ and the formation of the corresponding hydrogenated by-product $\mathbf{3 a}$, resulting of the dehalogenation reaction of $\mathbf{1 a}$, in a $72 / 28$ ratio in favour of $\mathbf{2 a}$. Interestingly, the addition of $20 \mathrm{~mol} \%$ of $\mathrm{CuI}$ inhibited the degradation, but diminished the rate of the reaction, so that a total conversion was only attained in $50 \mathrm{~min}$, and the formation of 3a was still observed in a 63/37 ratio in favour of 2a (entry 2). Under the same conditions, the increase of the concentration of $1 \mathbf{a}(0.5 \mathrm{M})$ allowed us to get total conversion in $20 \mathrm{~min}$ and dramatically diminished the formation of $\mathbf{3 a}$ (entry 3 ). Finally the use of $40 \mathrm{~mol} \%$ of $\mathrm{CuI}$ impressively decreased the reaction time to only $5 \mathrm{~min}$, with a good $\mathbf{2 a} / \mathbf{3 a}$ ratio 
(92/8, entry 4). Those optimized conditions were then applied to $\mathbf{1 b}$, allowing also a total conversion in 5 min, but still with some amount of the corresponding hydrogenated product $\mathbf{3 b}$ (entry 5 ).

Table 1. Methyl transfer reactions onto 1a-c.

\begin{tabular}{|c|c|c|c|c|}
\hline & $\sum_{\substack{\mathrm{OH} \\
\mathbf{a}, 1 \mathrm{~b}, 1}}^{\mathrm{OH}}$ & $\begin{array}{c}\mathrm{Sn}\left[\mathrm{N}(\mathrm{TMS})_{2}\right]_{2} \\
\stackrel{\mathrm{CH}_{3} \mathrm{l}, \mathrm{TBAF}}{\longrightarrow} \\
\mathrm{Pd}_{2} \mathrm{dba}_{3}(10 \mathrm{~mol} \%) \\
\mathrm{DMF}, 100^{\circ} \mathrm{C}\end{array}$ & , 2b, 2c (Me) & \\
\hline Entry & Compd. $\left[\right.$ mol.L $\left.{ }^{-1}\right]$ & $\mathrm{CuI}[\mathrm{mol} \%]$ & Time $^{[\mathrm{a}]}[\mathrm{min}]$ & $2 / 3^{[b]}$ \\
\hline 1 & $\mathbf{1 a}(0.2)$ & 0 & 5 & $\mathbf{2 a} / \mathbf{3 a}: 72 / 28^{[\mathrm{c}]}$ \\
\hline 2 & $\mathbf{1} \mathbf{a}(0.2)$ & 20 & 50 & $\mathbf{2 a} / \mathbf{3 a}: 63 / 37$ \\
\hline 3 & $\mathbf{1 a}(0.5)$ & 20 & 20 & $\mathbf{2 a} / \mathbf{3 a}: 97 / 3$ \\
\hline 4 & $\mathbf{1} \mathbf{a}(0.5)$ & 40 & 5 & $\mathbf{2 a} / \mathbf{3 a}: 92 / 8$ \\
\hline 5 & $1 b(0.5)$ & 40 & 5 & $\mathbf{2 b} / \mathbf{3 b}: 80 / 20$ \\
\hline 6 & $1 \mathrm{c}(0.5)$ & 40 & 50 & $\mathbf{2 c} / \mathbf{3 c}: 100 / 0$ \\
\hline 7 & $1 \mathrm{c}(0.5)$ & 140 & 5 & 2c/3c: $100 / 0$ \\
\hline
\end{tabular}

${ }^{[\mathrm{a}]}$ For total conversion. ${ }^{[\mathrm{b}]}$ Estimated by HPLC. ${ }^{[\mathrm{c}]}$ With degradation estimated to $20 \%$.

Finally, when the optimized conditions of 1a were applied to 1c, a total conversion was observed after $50 \mathrm{~min}$, but in this case, the sole methylated compound $\mathbf{2 c}$ was formed (entry 6). In order to explain the increase of the reaction time, we could envisage that the copper is coordinated by the oxygen atoms of the ethylene glycol arm keeping it unavailable for the catalytic cycle of the Stille coupling. Indeed, the use of $140 \mathrm{~mol} \%$ of $\mathrm{CuI}$ allowed us to recover a total conversion in $5 \mathrm{~min}$ again with

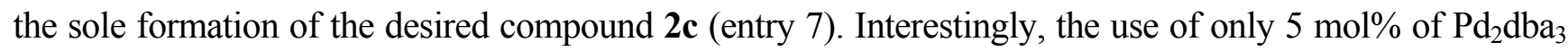
with $20 \mathrm{~mol} \%$ of $\mathrm{CuI}$ led to total conversion in $5 \mathrm{~min}$ with a better $\mathbf{2 b} / \mathbf{3} \mathbf{b}$ ratio of $93 / 7$ under classical heating conditions (to be compared to entry 5), and in 2 min with a $\mathbf{2 b} / \mathbf{3 b}$ ratio of $96 / 4$ under microwave activation.

Thus, having in hand conditions allowing a few minutes reaction time, compatible with the half-life of carbon-11 and unprotected nucleosides, we wanted to extend this methodology to oligonucleotides (ODNs). The first difficulty was related to the concentration of the substrate and the palladium charge. Indeed, ODNs are produced in such small quantities that running a methyl transfer reaction using an ODN concentration of $0.5 \mathrm{M}$ and $10 \mathrm{~mol} \%$ of $\mathrm{Pd}_{2} \mathrm{dba}_{3}$ was not possible. The second point was the low solubility of ODNs in DMF. Finally, the third question concerned the compatibility of our conditions with the phosphodiester linkage of ODNs. In order to address those three questions, we studied first the methyl tranfer on $1 \mathbf{b}$ at $5 \times 10^{-3} \mathrm{M}$, with $100 \mathrm{~mol} \%$ of $\mathrm{Pd}_{2} \mathrm{dba}_{3}$, at $100{ }^{\circ} \mathrm{C}$ in various solvents under classical or microwave heating conditions (Table 2). The direct transposition of the previous conditions using a $\mathrm{Pd} / \mathrm{Cu}$ ratio of $1 / 2$ (entry 1 ) led to a strong decrease of the reaction rate, as the total conversion was only observed after $60 \mathrm{~min}$ with a similar ratio $\mathbf{2 b} / \mathbf{3 b}$. Furthermore, the increase of the amount of $\mathrm{CuI}$ totally inhibited the reaction (entry 2). On the contrary, the absence of CuI allowed to recover a total conversion in $5 \mathrm{~min}$ with a better $\mathbf{2 b} / \mathbf{3} \mathbf{b}$ ratio of $90 / 10$ (entry 3 ). Under the same 
conditions, the use of microwave irradiation instead of classical heating did not result in any improvements (entry 4).

Table 2. Methyl transfer onto $\mathbf{1 b}$ under dilute conditions $\left(5 \times 10^{-3} \mathrm{M}\right)$.

\begin{tabular}{|c|c|c|c|c|c|}
\hline Entry & Solvent & CuI [mol\%] & MW & Time [min] ${ }^{[a]}$ & $2 / 3^{[b]}$ \\
\hline 1 & DMF & 400 & no & 60 & $81 / 19^{[\mathrm{cc}]}$ \\
\hline 2 & DMF & 2000 & no & - & - \\
\hline 3 & DMF & 0 & no & 5 & $90 / 10$ \\
\hline 4 & DMF & 0 & yes & 5 & $89 / 11$ \\
\hline 5 & $\begin{array}{c}\text { DMF/DMSO } \\
9 / 1\end{array}$ & 0 & no & 5 & $66 / 34^{[\mathrm{c}]}$ \\
\hline 6 & $\begin{array}{c}\mathrm{DMF} / \mathrm{DMSO} \\
9 / 1\end{array}$ & 0 & yes & 5 & $96 / 4$ \\
\hline 7 & $\begin{array}{c}\text { DMF/DMSO } \\
3 / 1\end{array}$ & 0 & yes & 5 & $91 / 9$ \\
\hline 8 & $\begin{array}{c}\mathrm{DMF} / \mathrm{H}_{2} \mathrm{O} \\
9.5 / 0.5\end{array}$ & 0 & no & 40 & $54 / 46^{[\mathrm{c}]}$ \\
\hline 9 & $\begin{array}{c}\mathrm{DMF} / \mathrm{H}_{2} \mathrm{O} \\
9.5 / 0.5\end{array}$ & 0 & yes & 5 & $85 / 15$ \\
\hline 10 & $\begin{array}{c}\mathrm{DMF} / \mathrm{H}_{2} \mathrm{O} \\
9 / 1\end{array}$ & 0 & yes & 5 & $60 / 40$ \\
\hline
\end{tabular}

${ }^{[\mathrm{a}]}$ For total conversion. ${ }^{[\mathrm{b}]}$ Estimated by HPLC. ${ }^{[\mathrm{c}]}$ With impurities estimated to less than $10 \%$.

However, addition of 10\% DMSO in DMF, under classical heating led to an increased formation of the hydrogenated product 3b (34\%) together with apparition of side products (entry 5), while microwave heating, under the same conditions (entry 6), allowed us to get a clean reaction with a 96/4 $\mathbf{2 b} / \mathbf{3 b}$ ratio. The increase of the proportion of DMSO under microwaves (entry 7), led to an almost similar $\mathbf{2 b} / \mathbf{3 b}$ ratio. The use of $\mathrm{H}_{2} \mathrm{O}$ instead of DMSO, even in a very small quantity, under classical heating, seriously disturbed the rate of the reaction and the formation of the methylated compound (entry 8). The use of microwaves in the same conditions allowed us to recover a total conversion in $5 \mathrm{~min}$ with quite a good $\mathbf{2 b} / \mathbf{3} \mathbf{b}$ ratio (entry 9). Finally, even a slight increase of the proportion of $\mathrm{H}_{2} \mathrm{O}$ was not appropriate at all (entry 10). After the achievement of the procedure optimization on the monomeric substrates, the last step was to test our best conditions on the dinucleotide $\mathbf{4}$ synthesized as a 70/30 mixture of diastereomers according to the standard phosphoramidite method from the 5'C-substituted nucleoside from $\mathbf{1 b}[19,20]$.

Thus, 4 was used at a $5 \times 10^{-3} \mathrm{M}$ concentration in a mixture of DMF/DMSO (9/1), with $100 \mathrm{~mol} \%$ of $\mathrm{Pd}_{2} \mathrm{dba}_{3}$ (Scheme 2). The reaction was run at $100{ }^{\circ} \mathrm{C}$, under microwave heating, leading to a total conversion into the single desired methylated compound 5 in $5 \mathrm{~min}$. Noteworthily, the increase of the DMSO/DMF ratio up to $1 / 1$ only slightly perturbed the reaction, as the total conversion was still obtained in $5 \mathrm{~min}$, but we could observe the formation of the corresponding hydrogenated compound in a 87/13 ratio in favour of 5 . 
Scheme 2. Methyl transfer study onto dinucleotide 4.

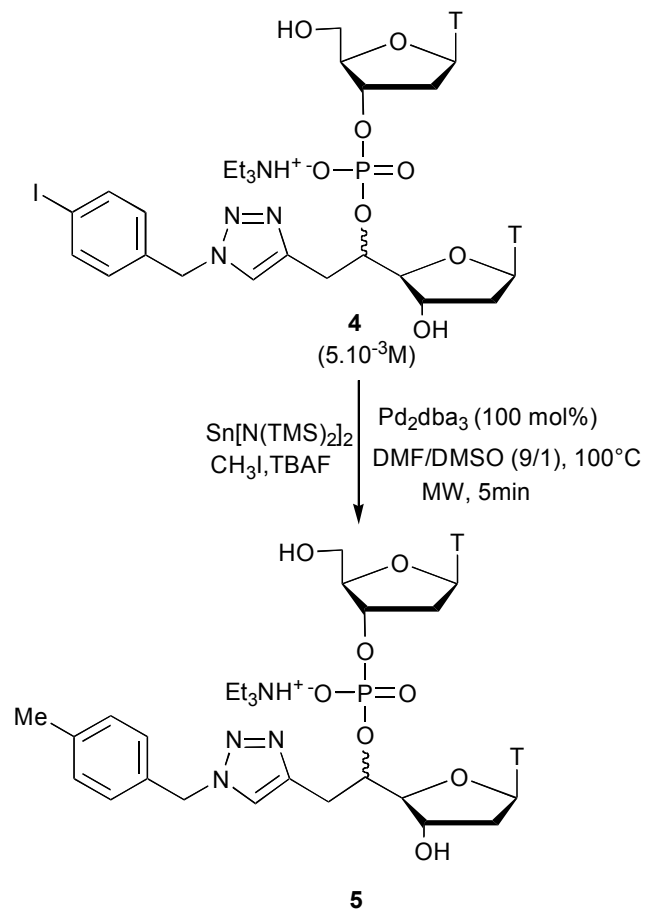

\section{Experimental}

\subsection{General}

All water-sensitive reactions were carried out under a nitrogen atmosphere with dry solvents under anhydrous conditions. Yields refer to chromatographically and spectroscopically ( ${ }^{1} \mathrm{H}$ NMR) homogeneous materials. Macherey Nagel silica gel 60M (230-400 mesh ASTM) was used for flash chromatography. $\mathrm{CH}_{2} \mathrm{Cl}_{2}$ and $(i \text {-Pr) })_{2} \mathrm{NH}$ were distilled over $\mathrm{CaH}_{2}$. THF and $\mathrm{Et}_{2} \mathrm{O}$ were distilled from sodium and benzophenone. Ethanol and methanol were dried over magnesium turnings activated by iodine. Micro-wave assisted reaction were carried out on a Biotage Initiator. HPLC was performed on a Waters 600 system equipped with a Waters 996 photodiode array detector. Analytical and semi-preparative HPLC were performed with a reversed-phase column (Phenomenex Luna C18, $5 \mu \mathrm{m}$, $250 \times 4.6 \mathrm{~mm}$ and Kromasil C18, $5 \mu \mathrm{m}, 250 \times 20 \mathrm{~mm}$ ) using the following solvent systems at $1 \mathrm{~mL} / \mathrm{min}$ and $4 \mathrm{~mL} / \mathrm{min}$ : Acetonitrile (solvent A) and $\mathrm{H}_{2} \mathrm{O}$ MilliQ (solvent $\mathrm{C}$ ) for reactions on modified thymidines, Acetonitrile (solvent $\mathrm{A}$ ) and $\mathrm{TEAA}_{\mathrm{aq}}$ (triethylammonium acetate) $50 \mathrm{mM}$ at $\mathrm{pH}=7$ (solvent B) for reactions on modified dinucleotide. ${ }^{1} \mathrm{H}-\mathrm{NMR}$ and ${ }^{13} \mathrm{C}-\mathrm{NMR}$ were recorded on Bruker DPX-200 FT $\left({ }^{1} \mathrm{H}: 200 \mathrm{MHz},{ }^{13} \mathrm{C}: 50.2 \mathrm{MHz}\right)$, Bruker AC-250 FT $\left({ }^{1} \mathrm{H}: 250 \mathrm{MHz},{ }^{13} \mathrm{C}: 62.9 \mathrm{MHz}\right)$, Bruker AVANCE-300 FT $\left({ }^{1} \mathrm{H}: 300 \mathrm{MHz},{ }^{13} \mathrm{C}: 75.5 \mathrm{MHz}\right)$ and Bruker DPX-400 FT $\left({ }^{1} \mathrm{H}: 400 \mathrm{MHz}\right.$, ${ }^{13} \mathrm{C}: 100.2 \mathrm{MHz}$ ) apparatus using indicated internal reference. The chemical shifts $(\delta)$ and coupling constants $(J)$ are expressed in ppm and $\mathrm{Hz}$ respectively. Mass spectra were recorded on a Nermag R10-10C. High resolution mass spectra were performed by the CESAMO (Talence, France) and were recorded on a FT-IRC mass spectrometer Bruker 4.7T BioApex II. MALDI-MS spectra were performed by the CESAMO (Talence, France) on a Voyager mass spectrometer (Applied Biosystems). 


\subsection{Preparation of $\mathbf{4}$}

Dinucleotide 4 was prepared in four steps from the 3'-O-TBDPS derivative of $\mathbf{1 b}$, as follows:

\subsubsection{Coupling (4DCT)}

The 3'-O-TBDPS derivative of $\mathbf{1 b}(1.24 \mathrm{~g}, 1.6 \mathrm{mmol})$, the commercially available 3'-O-(2cyanoethyl diisopropylphosphoramidite)-5'-O-DMTr-thymidine (4 g, $5.33 \mathrm{mmol}, 3.3 \mathrm{eq}$.) and a solution of tetrazole $\left(0.45 \mathrm{M}\right.$ in $\mathrm{CH}_{3} \mathrm{CN}, 47 \mathrm{~mL}, 210 \mathrm{mmol}, 13$ eq. $)$ were stirred $30 \mathrm{~min}$ at room temperature. Then collidine $\left(2.75 \mathrm{~mL}, 20.8 \mathrm{mmol}, 13\right.$ equiv.) and an excess of a solution of $\mathrm{I}_{2}$ [0.1 $\mathrm{M}$ in $\left.\mathrm{THF} / \mathrm{H}_{2} \mathrm{O}(2: 1)\right]$ were added. Then a solution of $\mathrm{Na}_{2} \mathrm{~S}_{2} \mathrm{O}_{3}$ was added until the reaction mixture remained colorless. The mixture was diluted with $200 \mathrm{~mL}$ of ethyl acetate, washed with $\mathrm{H}_{2} \mathrm{O}$ $(2 \times 100 \mathrm{~mL})$ and brine $(100 \mathrm{~mL})$. The organic layer was dried over $\mathrm{MgSO}_{4}$ and evaporated to dryness under vacuum. The crude product was purified by flash chromatography by flash purification (ethyl acetate $\left./ \mathrm{CH}_{2} \mathrm{Cl}_{2}: 1 / 1 \rightarrow 8 / 2 \rightarrow 1 / 0\right)$ affording the all protected dinucleotide 4DCT (1.78 g, 78\% yield) as a white foam. ${ }^{1} \mathrm{H}-\mathrm{NMR}\left(400 \mathrm{MHz}, \mathrm{CDCl}_{3}\right.$ ), $\delta_{\mathrm{ppm}}: 1.03$ (s, 9H, $\left.\mathrm{CH}_{3} t \mathrm{Bu}\right), 1.35-1.39$ (m, 3H, $\mathrm{CH}_{3}$ thymine), 1.82-1.93 (m, 4H, $\mathrm{H}_{2^{\prime}}$ and $\mathrm{CH}_{3}$ thymine), 2.31-2.42 (m, 5H, $\mathrm{H}_{2^{\prime}}, \mathrm{H}_{2^{\prime \prime}}$ and $\mathrm{C}_{2} \mathrm{CN}$ ), 2.51-2.54 (m, $1 \mathrm{H}, \underline{\mathrm{C}}_{2} \mathrm{CN}$ CEO), 2.72-2.98 (m, 2H, $\left.\mathrm{H}_{6}\right), 3.28-3.49$ (m, 2H, $\left.\mathrm{CH}_{2}-\mathrm{O}\right), 3.76-3.89\left(\mathrm{~m}, 7 \mathrm{H}, \mathrm{H}_{5^{\prime \prime}}\right.$ and $\mathrm{CH}_{3}$ DMTr), 3.93-4.06 (m, 3H, $\mathrm{H}_{5^{\prime \prime}}, \mathrm{H}_{4^{\prime}}$ and $\left.\mathrm{H}_{4^{\prime \prime}}\right), 4.21-4.32\left(\mathrm{~m}, 1 \mathrm{H}, \mathrm{H}_{3^{\prime \prime}}\right), 4.40\left(\mathrm{~s}, 1 \mathrm{H}, \mathrm{H}_{5^{\prime}}\right), 5.01-5.04$ $\left(\mathrm{m}, 1 \mathrm{H}, \mathrm{H}_{3^{\prime}}\right), 5.41\left(\mathrm{~s}, 2 \mathrm{H}, \mathrm{H}_{9^{\prime}}\right), 6.23-6.30\left(\mathrm{~m}, 1 \mathrm{H}, \mathrm{H}_{1^{\prime \prime}}\right), 6.45-6.55\left(\mathrm{~m}, 1 \mathrm{H}, \mathrm{H}_{1^{\prime}}\right), 6.83(\mathrm{~d}, 4 \mathrm{H}, J=5.9 \mathrm{~Hz}$, CH DMTr), 6.98 and $7.03\left(2 \mathrm{~d}, 2 \mathrm{H}, J=10.0 \mathrm{~Hz}, \mathrm{H}_{11^{\prime}}\right.$ and $\left.\mathrm{H}_{15^{\prime}}\right), 7.21-7.36\left(\mathrm{~m}, 16 \mathrm{H}, \mathrm{H} 8^{\prime}\right.$, CH phenyl and $\mathrm{CH}$ DMTr), 7.53-7.69 (m, 8H, $\mathrm{H}_{12}, \mathrm{H}_{14}, \mathrm{CH}$ thymine and $\mathrm{CH}$ phenyl), 8.81 (s, 2H, NH thymine). ${ }^{13} \mathrm{C}-\mathrm{NMR}\left(100.2 \mathrm{MHz}, \mathrm{CDCl}_{3}\right), \delta_{\mathrm{ppm}}: 11.8$ and $12.8\left(\mathrm{CH}_{3}\right.$ thymine), $19.3(\mathrm{C} t \mathrm{Bu}), 19.53$ and 19.81 $\left(\underline{\mathrm{CH}_{2} \mathrm{CN}}\right), 27.1\left(\mathrm{CH}_{3} t \mathrm{Bu}\right), 29.0\left(\mathrm{C}_{6^{\prime}}\right), 38.9$ and $39.0\left(\mathrm{C}_{2^{\prime \prime}}\right), 40.1$ and $40.1\left(\mathrm{C}_{2^{\prime}}\right), 53.6$ and $53.7\left(\mathrm{C}_{9^{\prime}}\right), 55.5$ $\left(\mathrm{CH}_{3}\right.$ DMTr$), 62.4$ and $62.7\left(\mathrm{C}_{5^{\prime \prime}}\right), 63.4$ and $63.6\left(\mathrm{CH}_{2} \mathrm{O}\right), 74.6\left(\mathrm{C}_{5^{\prime}}\right), 79.2$ and $80.1\left(\mathrm{C}_{3^{\prime}}\right.$ and $\left.\mathrm{C}_{3^{\prime \prime}}\right), 84.2$ and $85.2\left(\mathrm{C}_{1^{\prime}}, \mathrm{C}_{1^{\prime \prime}}\right.$ and $\left.\mathrm{C}_{4^{\prime \prime}}\right), 87.5\left(\mathrm{C}_{4^{\prime}}\right), 94.7$ and $94.8\left(\mathrm{C}_{13^{\prime}}\right), 111.6$ and $112.2(\mathrm{C}$ thymine $), 113.6(\mathrm{CH}$ DMTr), 116.4 and $116.9(\mathrm{CN}), 122.3$ and 123.0 (CH DMTr), $127.5(\mathrm{CH}$ phenyl), 128.3 and $128.4(\mathrm{CH}$ DMTr), $129.4\left(\mathrm{C}_{8^{\prime}}\right), 130.1$ and $130.2\left(\mathrm{C}_{11^{\prime}}\right.$ and $\left.\mathrm{C}_{15^{\prime}}\right), 130.4(\mathrm{CH}$ phenyl), 132.7 and 133.1 ( $\mathrm{C}$ phenyl and $\left.\mathrm{C}_{10^{\prime}}\right), 134.6$ and 135.5 (C DMTr), 135.9 ( $\mathrm{CH}$ thymine and $\mathrm{CH}$ phenyl), 138.4 and $138.5\left(\mathrm{C}_{12^{\prime}}\right.$ and $\left.\mathrm{C}_{14^{\prime}}\right)$, 142.6 (C DMTr), $144.2\left(\mathrm{C}_{7}\right), 150.8$ and 151.1 (C DMTr and $\mathrm{C}=\mathrm{O}$ thymine), 159.1 (C-OMe DMTr), $164.1\left(\mathrm{C}=\mathrm{O}\right.$ thymine). ${ }^{31} \mathrm{P}-\mathrm{NMR}\left(121.6 \mathrm{MHz}, \mathrm{CDCl}_{3}\right), \delta_{\mathrm{ppm}}:-3.63$ and -3.06 . MALDI-TOF, $\mathrm{m} / z$ : $1459.3\left(\left[\mathrm{M}+\mathrm{Na}^{+}\right]^{+}\right), 1475.2\left(\left[\mathrm{M}+\mathrm{K}^{+}\right]^{+}\right)$.

\subsubsection{Cleavage of DMTr Group (4CT)}

To a solution of 4DCT (450 mg, $0.31 \mathrm{mmol}$.) in $\mathrm{CH}_{2} \mathrm{Cl}_{2}(3 \mathrm{~mL})$ was added TFA (90 $\mu \mathrm{L}, 1.2 \mathrm{mmol}$, 3.9 equiv.). The clearly red solution was stirred $30 \mathrm{~min}$ at room temperature. The solvent was evaporated under vacuum and the crude product was purified by flash chromatography (ethyl acetate/methanol: 100/0 $\rightarrow$ 95/5) affording 4CT (350 mg, 98\% yield) as a white foam. ${ }^{1} \mathrm{H}-\mathrm{NMR}$ (400 MHz, $\mathrm{CDCl}_{3}$ ), $\delta_{\mathrm{ppm}}: 1.03\left(\mathrm{~s}, 9 \mathrm{H}, \mathrm{CH}_{3} \mathrm{Bu}\right), 1.24\left(\mathrm{~m}, 1 \mathrm{H}, \mathrm{H}_{6}\right), 1.83$ (s, 3H, $\mathrm{CH}_{3}$ thymine), 2.27-2.75 (m, 7H, $\mathrm{H}_{6^{\prime}}, \mathrm{H}_{2^{\prime}}, \mathrm{H}_{2^{\prime \prime}}$ and $\mathrm{CH}_{2} \mathrm{CN}$ ), 3.74-4.01 (m, 7H, $\mathrm{H}_{5^{\prime}}, \mathrm{H}_{5^{\prime \prime}}, \mathrm{H}_{4^{\prime}}, \mathrm{OH}$ and $\left.\mathrm{CH}_{2} \mathrm{O}\right), 4.40\left(\mathrm{~s}, 2 \mathrm{H}, \mathrm{H}_{4^{\prime \prime}}\right.$ and $\left.\mathrm{H}_{3^{\prime \prime}}\right), 4.97\left(\mathrm{~m}, 1 \mathrm{H}, \mathrm{H}_{3^{\prime}}\right), 5.42\left(\mathrm{~s}, 2 \mathrm{H}, \mathrm{H}_{9^{\prime}}\right), 6.01-6.39\left(\mathrm{~m}, 2 \mathrm{H}, \mathrm{H}_{1^{\prime}}\right.$ and $\left.\mathrm{H}_{1^{\prime \prime}}\right), 7.01\left(2 \mathrm{~d}, 2 \mathrm{H}, J=8.0 \mathrm{~Hz}, \mathrm{H}_{11^{\prime}}\right.$ and $\left.\mathrm{H}_{15^{\prime}}\right), 7.35-7.42\left(\mathrm{~m}, 9 \mathrm{H}, \mathrm{H}_{8^{\prime}}\right.$ and $\mathrm{CH}$ phenyl), 7.58-7.62 (m, 4H, $\mathrm{CH}$ phenyl and $\mathrm{CH}$ thymine), 7.68 
$\left(2 \mathrm{~d}, 2 \mathrm{H}, J=8.0 \mathrm{~Hz}, \mathrm{H}_{12}\right.$ and $\left.\mathrm{H}_{14}\right), 9.73\left(\mathrm{~s}, 2 \mathrm{H}, \mathrm{NH}\right.$ thymine). ${ }^{13} \mathrm{C}-\mathrm{NMR}\left(100.2 \mathrm{MHz}, \mathrm{CDCl}_{3}\right), \delta_{\mathrm{ppm}}$ : $12.4\left(\mathrm{CH}_{3}\right.$ thymine $), 19.00\left(\mathrm{CH}_{2} \mathrm{CN}\right.$ and $\left.\mathrm{C} t \mathrm{Bu}\right), 26.9\left(\mathrm{CH}_{3} t \mathrm{Bu}\right), 29.8\left(\mathrm{C}_{6}{ }^{\prime}\right), 38.3\left(\mathrm{C}_{2^{\prime}}\right.$ and $\left.\mathrm{C}_{2^{\prime \prime}}\right), 53.4$ $\left(\mathrm{C}_{9^{\prime}}\right), 60.5\left(\mathrm{C}_{5^{\prime}}\right.$ and $\left.\mathrm{C}_{5^{\prime \prime}}\right), 62.7\left(\mathrm{CH}_{2} \mathrm{O}\right), 74.5\left(\mathrm{C}_{4^{\prime \prime}}\right), 79.4$ and $79.6\left(\mathrm{C}_{3^{\prime}}\right), 85.7\left(\mathrm{C}_{1^{\prime}}\right.$ and $\left.\mathrm{C}_{1^{\prime \prime}}\right), 87.7\left(\mathrm{C}_{4^{\prime}}\right)$, $94.8\left(\mathrm{C}_{13^{\prime}}\right), 111.8(\mathrm{CN}), 115.1$ and 117.9 (C thymine), $123.3\left(\mathrm{C}_{8^{\prime}}\right), 128.3(\mathrm{CH}$ phenyl), 130.1 and 130.3 $\left(\mathrm{C}_{11^{\prime}}\right.$ and $\left.\mathrm{C}_{15^{\prime}}\right), 132.8-133.1$ (C phenyl), 134.6-134.7 $\left(\mathrm{C}_{10^{\prime}}\right), 135.9(\mathrm{CH}$ thymine $), 138.4\left(\mathrm{C}_{12^{\prime}}\right.$ and $\left.\mathrm{C}_{14^{\prime}}\right)$, $142.6\left(\mathrm{C}_{7}\right), 151.0(\mathrm{C}=\mathrm{O}$ thymine $), 164.5-164.7(\mathrm{C}=\mathrm{O}$ thymine $) .{ }^{31} \mathrm{P}-\mathrm{NMR}\left(121.6 \mathrm{MHz}, \mathrm{CDCl}_{3}\right)$, $\delta_{\mathrm{ppm}}:-3.26$. MALDI-TOF, $m / z: 1157.4\left(\left[\mathrm{M}+\mathrm{Na}^{+}\right]^{+}\right)$.

\subsubsection{Cleavage of Cyanoethyl Group (4T)}

To a solution of 4 CT $(190 \mathrm{mg}, 0.17 \mathrm{mmol})$ in $\mathrm{CH}_{3} \mathrm{CN}(3.4 \mathrm{~mL})$ was added $\mathrm{Et}_{3} \mathrm{~N}(350 \mu \mathrm{L}, 2.49 \mathrm{mmol}$, 15 equiv.). The reaction mixture was stirred $1 \mathrm{~h}$ at $60{ }^{\circ} \mathrm{C}$. The solvents were evaporated under vacuum affording 4T under the triethylammonium salt form (170 mg, 86\% yield) as a white foam. ${ }^{1} \mathrm{H}-\mathrm{NMR}$ (400 MHz, MeOD), $\delta_{\text {ppm }} 1.01\left(\mathrm{CH}_{3} t \mathrm{Bu}\right), 1.28\left(\mathrm{t}, 9 \mathrm{H}, J=8.0 \mathrm{~Hz}, \mathrm{CH}_{3} \mathrm{Et}_{3} \mathrm{NH}^{+}\right), 1.88$ and $1.89(2 \mathrm{~s}, 6 \mathrm{H}$, $\mathrm{CH}_{3}$ thymidine), 2.07-2.23 (m, $4 \mathrm{H}, \mathrm{H}_{2^{\prime}}$ and $\left.\mathrm{H}_{2^{\prime \prime}}\right), 3.05\left(\mathrm{t}, 1 \mathrm{H}, J=8.0 \mathrm{~Hz}, \mathrm{H}_{6}\right), 3.17(\mathrm{q}, 7 \mathrm{H}, J=8.0 \mathrm{~Hz}$, $\mathrm{H}_{6^{\prime}}$ and $\left.\mathrm{CH}_{2} \mathrm{Et}_{3} \mathrm{NH}^{+}\right), 3.70\left(\mathrm{~s}, 2 \mathrm{H}, \mathrm{H}_{5^{\prime}}\right), 3.85\left(\mathrm{~s}, 2 \mathrm{H}, \mathrm{H}_{4^{\prime}}\right.$ and $\left.\mathrm{H}_{4^{\prime \prime}}\right), 4.01-4.09\left(\mathrm{~m}, 1 \mathrm{H}, \mathrm{H}_{5^{\prime}}\right), 4.61\left(\mathrm{~s}, 1 \mathrm{H}, \mathrm{H}_{3^{\prime}}\right)$, $4.77\left(\mathrm{~s}, 1 \mathrm{H}, \mathrm{H}_{3^{\prime \prime}}\right), 5.51\left(\mathrm{~s}, 2 \mathrm{H}, \mathrm{H}_{9^{\prime}}\right), 6.11\left(\mathrm{t}, 1 \mathrm{H}, J=4.0 \mathrm{~Hz}, \mathrm{H}_{1^{\prime \prime}}\right), 6.58\left(\mathrm{t}, 1 \mathrm{H}, J=8.0 \mathrm{~Hz}, \mathrm{H}_{1^{\prime}}\right), 7.08(2 \mathrm{~d}$, $2 \mathrm{H}, J=12.0 \mathrm{~Hz}, \mathrm{H}_{11^{\prime}}$ and $\left.\mathrm{H}_{15^{\prime}}\right), 7.24-7.42(\mathrm{~m}, 8 \mathrm{H}, \mathrm{CH}$ phenyl), $7.56(\mathrm{~d}, 2 \mathrm{H}, J=8.0 \mathrm{~Hz}, \mathrm{CH}$ phenyl), $7.64\left(\mathrm{~d}, 2 \mathrm{H}, J=8 \mathrm{~Hz}, \mathrm{H}_{12}\right.$ and $\left.\mathrm{H}_{14^{\prime}}\right), 7.77\left(2 \mathrm{~s}, 2 \mathrm{H}, \mathrm{H}_{8^{\prime}}\right.$ and $\mathrm{CH}$ thymine), 7.89 (s, 1H, $\mathrm{CH}$ thymine). ${ }^{13} \mathrm{C}-\mathrm{NMR}(100.2 \mathrm{MHz}, \mathrm{MeOD}), \delta_{\mathrm{ppm}}: 9.35\left(\mathrm{CH}_{3} \mathrm{HNEt}_{3}{ }^{+}\right), 12.7$ and $12.9\left(\mathrm{CH}_{3}\right.$ thymine $), 27.6\left(\mathrm{CH}_{3} \mathrm{tBu}\right)$, $29.7\left(\mathrm{C}_{6^{\prime}}\right), 40.1\left(\mathrm{C}_{2^{\prime}}\right) 41.1\left(\mathrm{C}_{2^{\prime \prime}}\right), 46.9\left(\mathrm{CH}_{2} \mathrm{Et}_{3} \mathrm{NH}^{+}\right), 54.4\left(\mathrm{C}_{9^{\prime}}\right), 62.6\left(\mathrm{C}_{5^{\prime \prime}}\right), 76.5\left(\mathrm{C}_{3^{\prime \prime}}\right), 76.6\left(\mathrm{C}_{5^{\prime}}\right), 77.3$ $\left(\mathrm{C}_{3^{\prime}}\right), 86.0\left(\mathrm{C}_{1^{\prime}}\right.$ and $\left.\mathrm{C}_{1^{\prime \prime}}\right), 86.8\left(\mathrm{C}_{4^{\prime}}\right), 87.5\left(\mathrm{C}_{4^{\prime \prime}}\right), 95.1\left(\mathrm{C}_{13^{\prime}}\right), 111.6$ and $112.3(\mathrm{C}$ thymine $), 124.9\left(\mathrm{C}_{8^{\prime}}\right)$, $129.2\left(\mathrm{C}_{11}, \mathrm{C}_{15}\right.$ and $\mathrm{CH}$ phenyl), $131.3\left(\mathrm{C}_{10}\right.$ and $\mathrm{C}$ phenyl), 136.8 ( $\mathrm{CH}$ phenyl), 137.1 ( $\mathrm{CH}$ phenyl), 138.3 ( $\mathrm{CH}$ thymine), $139.4\left(\mathrm{C}_{12^{\prime}}\right.$ and $\left.\mathrm{C}_{14^{\prime}}\right), 144.7\left(\mathrm{C}_{7^{\prime}}\right), 152.3$ and $152.7(\mathrm{C}=\mathrm{O}$ thymine $), 166.4(\mathrm{C}=\mathrm{O}$ thymine). ${ }^{31} \mathrm{P}-\mathrm{NMR}(121.6 \mathrm{MHz}, \mathrm{MeOD}) \delta_{\mathrm{ppm}}:-2.14$. MALDI-TOF, $m / z: 1078.8\left(\left[\mathrm{M}-\mathrm{Et}_{3} \mathrm{NH}^{+}\right]^{-}\right)$.

\subsubsection{Cleavage of TBDPS p: Preparation of Compound 4}

To a solution of $4 \mathrm{~T}$ (170 mg, $0.14 \mathrm{mmol}, 1$ eq.) in $\mathrm{CH}_{3} \mathrm{CN}$ (2 mL, HPLC grade) was added a solution of TBAF [( $1 \mathrm{M}$ in THF), $170 \mu \mathrm{L}, 0.17 \mathrm{mmol}, 1.2$ equiv.]. The reaction mixture was stirred overnight at room temperature. The solvent was evaporated under vacuum and the crude product was purified by precipitation in $\mathrm{Et}_{2} \mathrm{O}$ affording 4, under the triethylammonium salt form, (105 $\mathrm{mg}, 77 \%$ yield) as white foam. ${ }^{1} \mathrm{H}-\mathrm{NMR}(300 \mathrm{MHz}, \mathrm{MeOD}), \delta_{\mathrm{ppm}}: 1.30\left(\mathrm{t}, 9 \mathrm{H}, J=7.1 \mathrm{~Hz}, \mathrm{CH}_{3} \mathrm{Et}_{3} \mathrm{NH}^{+}\right.$), 1.59-1.72 (m, $\left.2 \mathrm{H}, \mathrm{H}_{6^{\prime}}\right), 1.86\left(\mathrm{~s}, 3 \mathrm{H}, \mathrm{CH}_{3}\right.$ thymine), 1.93 (s, 3H, $\mathrm{CH}_{3}$ thymine), 2.20-2.51 (m, $4 \mathrm{H}, \mathrm{H}_{2^{\prime}}$ and $\left.\mathrm{H}_{2^{\prime \prime}}\right), 3.15-3.27$ (m, 7H, $\mathrm{H}_{5^{\prime}}$ and $\mathrm{CH}_{2} \mathrm{Et}_{3} \mathrm{NH}^{+}$), 3.79-3.83 (m, 3H, $\mathrm{H}_{4^{\prime}}$ and $\left.\mathrm{H}_{5^{\prime \prime}}\right), 4.11-4.16\left(\mathrm{~m}, 1 \mathrm{H}, 4^{\prime \prime}\right)$, 4.57-4.72 (m, 2H, $\mathrm{H}_{3^{\prime}}$ and $\left.\mathrm{H}_{3^{\prime \prime}}\right), 5.54\left(\mathrm{~s}, 2 \mathrm{H}, \mathrm{H}_{9^{\prime}}\right), 6.19-6.43\left(\mathrm{~m}, 2 \mathrm{H}, \mathrm{H}_{1^{\prime}}\right.$ and $\left.\mathrm{H}_{1^{\prime \prime}}\right), 7.07(\mathrm{~d}, 2 \mathrm{H}, J=8.3 \mathrm{~Hz}$, $\mathrm{H}_{11^{\prime}}$ and $\left.\mathrm{H}_{15^{\prime}}\right), 7.67\left(\mathrm{~d}, 2 \mathrm{H}, J=7.9 \mathrm{~Hz}, \mathrm{H}_{12^{\prime}}\right.$ and $\left.\mathrm{H}_{14^{\prime}}\right), 7.85(\mathrm{~d}, 1 \mathrm{H}, J=5.6 \mathrm{~Hz}, \mathrm{CH}$ thymine $), 7.93-7.96$ (m, $2 \mathrm{H}, \mathrm{H}_{8}$, and $\mathrm{CH}$ thymine). ${ }^{13} \mathrm{C}-\mathrm{NMR}(75.5 \mathrm{MHz}, \mathrm{MeOD}), \delta_{\mathrm{ppm}}: 9.2\left(\mathrm{CH}_{3} \mathrm{Et}_{3} \mathrm{NH}^{+}\right), 12.6$ and 12.9 $\left(\mathrm{CH}_{3}\right.$ thymine), $24.7\left(\mathrm{C}_{6^{\prime}}\right), 40.0$ and $40.6\left(\mathrm{C}_{2^{\prime}}\right.$ and $\left.\mathrm{C}_{2^{\prime}}\right), 47.6\left(\mathrm{CH}_{2} \mathrm{Et}_{3} \mathrm{NH}^{+}\right), 54.1\left(\mathrm{C}_{9^{\prime}}\right), 59.4\left(\mathrm{C}_{5^{\prime}}\right), 62.8$ $\left(\mathrm{C}_{5^{\prime \prime}}\right), 72.1$ and $77.1\left(\mathrm{C}_{3^{\prime}}\right.$ and $\left.\mathrm{C}_{3^{\prime \prime}}\right), 85.5$ and $86.0\left(\mathrm{C}_{1^{\prime}}\right.$ and $\left.\mathrm{C}_{1^{\prime \prime}}\right), 87.6$ and $88.0\left(\mathrm{C}_{4^{\prime}}\right.$ and $\left.\mathrm{C}_{4^{\prime \prime}}\right), 94.8\left(\mathrm{C}_{13^{\prime}}\right)$, 111.5 and $112.1\left(\mathrm{C}\right.$ thymine), $125.7\left(\mathrm{C}_{8^{\prime}}\right), 131.1\left(\mathrm{C}_{11^{\prime}}\right.$ and $\left.\mathrm{C}_{15^{\prime}}\right), 136.7$ and $138\left(\mathrm{C}_{7^{\prime}}, \mathrm{C}_{10^{\prime}}\right.$ and $\mathrm{CH}$ thymine), $139.1 \quad\left(\mathrm{C}_{12^{\prime}}\right.$ and $\left.\mathrm{C}_{14^{\prime}}\right), 152.17$ and $152.3(\mathrm{C}=\mathrm{O}$ thymine $), 166.2(\mathrm{C}=\mathrm{O}$ thymine). ${ }^{31} \mathrm{P}-\mathrm{NMR}$ (81.2 MHz, MeOD), $\delta_{\mathrm{ppm}}:-0.63$. MALDI-TOF, $m / z: 843.9\left(\left[\mathrm{M}+2 \mathrm{H}^{+}-\mathrm{Et}_{3} \mathrm{NH}^{+}\right]^{+}\right)$, 
$865.9\left(\left[\mathrm{M}+\mathrm{H}^{+}+\mathrm{Na}^{+}-\mathrm{Et}_{3} \mathrm{NH}^{+}\right]^{+}\right)$. HPLC: $\mathrm{rt}=17.15$ and $17.81 \mathrm{~min}(\mathrm{~A} / \mathrm{B}$ : from $20 / 80$ to $30 / 70$ in $15 \mathrm{~min}$ then to $50 / 50$ in $2 \mathrm{~min}$ then to $50 / 50$ during $2 \mathrm{~min}$ then to $20 / 80$ in $1 \mathrm{~min}$ ).

\subsection{General Procedure for Methylation (0.2 and $0.5 \mathrm{M})$}

According to the previously described procedure [12] the monomethylstannane was prepared from Lappert's stannylene and iodomethane. To a solution of monomethylstannane (2 equiv.) in THF ( $0.5 \mathrm{M})$, was added a commercial solution of TBAF $1 \mathrm{M}$ in THF (6 equiv.). The colourless resulting solution was stirred for $5 \mathrm{~min}$ and the solvent was removed under reduced pressure. The residue was dissolved in $\operatorname{DMF}(0.2$ or $0.5 \mathrm{M}) . \mathrm{Pd}_{2} \mathrm{dba}_{3}(10 \mathrm{~mol} \%), \mathrm{CuI}(0-140 \mathrm{~mol} \%)$ and the electrophile (1a, 1 b or $1 \mathrm{c}, 1$ equiv.) were added. The reaction mixture was stirred at $100{ }^{\circ} \mathrm{C}$ until total consumption of the starting material followed by HPLC (Phenomenex Luna C18, $5 \mathrm{~mm}, 250 \times 4.6 \mathrm{~mm}$ ). After cooling, the reaction mixture was diluted with methanol and the precipitate was filtrated. Solvents were evaporated under vacuum and the crude product was purified by semi-preparative HPLC (Kromasil C18, $5 \mathrm{~mm}, 250 \times 20 \mathrm{~mm}$ ).

(5'S)-C-(1-(Pent-3-enyl)-(4-(4-methylphenoxy)-methyl)-1H-1,2,3-triazol-1-yl)-thymidine (2a). HRMS (ESI), $m / z$ calculated for $\mathrm{C}_{25} \mathrm{H}_{31} \mathrm{~N}_{5} \mathrm{O}_{6} \mathrm{Na}\left(\left[\mathrm{M}+\mathrm{Na}^{+}\right]^{+}\right)$520.2166, found 520.2174. HPLC: $\mathrm{rt}=9.94$ (A/C: from $30 / 70$ to $70 / 30$ in $15 \mathrm{~min}$ then to $90 / 10$ in $1 \mathrm{~min}$ then to $40 / 60$ in $1 \mathrm{~min}$ ).

5'-C-(1-(4-Methyl-benzyl)-4-methyl-1H-1,2,3-triazol-4-yl)-thymidine (2b). ${ }^{1} \mathrm{H}-\mathrm{NMR} \quad(300 \mathrm{MHz}$, MeOD), $\delta_{\text {ppm }}: 1.85$ (s, 3H, $\mathrm{CH}_{3}$ thymine), 2.19-2.22 (m, 2H, $\left.\mathrm{H}_{2}\right), 2.29$ (s, 3H, $\left.\mathrm{CH}_{3}\right), 2.81-3.04(\mathrm{~m}, 2 \mathrm{H}$, $\left.\mathrm{H}_{6^{\prime}}\right), 3.76-3.81\left(\mathrm{~m}, 1 \mathrm{H}, \mathrm{H}_{4^{\prime}}\right), 4.00-4.10\left(\mathrm{~m}, 1 \mathrm{H}, \mathrm{H}_{5^{\prime}}\right), 4.40-4.56\left(\mathrm{~m}, 1 \mathrm{H}, \mathrm{H}_{3^{\prime}}\right), 5.48\left(\mathrm{~s}, 2 \mathrm{H}, \mathrm{H}_{9^{\prime}}\right), 6.22-6.32$ (m, $1 \mathrm{H}, \mathrm{H}_{1^{\prime}}$ ), 7.13-7.21 (m, 4H, $\mathrm{H}_{11^{\prime}}, \mathrm{H}_{12^{\prime}}, \mathrm{H}_{14^{\prime}}$ and $\mathrm{H}_{15^{\prime}}$ ), 7.67 (s, 0.3H, $\mathrm{CH}$ thymine), 7.75-7.76 (m, $\left.1 \mathrm{H}, \mathrm{H}_{8^{\prime}}\right), 7.96\left(\mathrm{~s}, 0.7 \mathrm{H}, \mathrm{CH}\right.$ thymine). ${ }^{13} \mathrm{C}-\mathrm{NMR}(75.5 \mathrm{MHz}, \mathrm{MeOD}), \delta_{\mathrm{ppm}}: 12.5\left(\mathrm{CH}_{3}\right.$ thymine), 21.2 $\left(\mathrm{CH}_{3}\right), 31.5\left(\mathrm{C}_{6^{\prime}}\right), 41.0\left(\mathrm{C}_{2^{\prime}}\right), 54.7\left(\mathrm{C}_{9^{\prime}}\right), 71.5\left(\mathrm{C}_{5^{\prime}}\right), 73.2\left(\mathrm{C}_{3^{\prime}}\right), 86.2\left(\mathrm{C}_{1^{\prime}}\right), 89.6$ and $90.5\left(\mathrm{C}_{4^{\prime}}\right), 111.6(\mathrm{C}$ thymine), $124.4\left(\mathrm{C}_{8^{\prime}}\right), 129.1\left(\mathrm{C}_{11^{\prime}}\right.$ and $\left.\mathrm{C}_{15^{\prime}}\right), 130.6\left(\mathrm{C}_{12^{\prime}}\right.$ and $\left.\mathrm{C}_{14^{\prime}}\right), 133.8\left(\mathrm{C}_{13^{\prime}}\right), 138.5$ (CH thymine), 139.5 $\left(\mathrm{C}_{10^{\prime}}\right), 146.0\left(\mathrm{C}_{7^{\prime}}\right), 152.4(\mathrm{C}=\mathrm{O}$ thymine$), 166.4(\mathrm{C}=\mathrm{O}$ thymine). HRMS (ESI) $\mathrm{m} / \mathrm{z}$ calculated for $\mathrm{C}_{21} \mathrm{H}_{26} \mathrm{~N}_{5} \mathrm{O}_{5} 428.1928$, found 428.1934. HPLC: $\mathrm{rt}=5.75 \mathrm{~min}(\mathrm{~A} / \mathrm{C}$ : from 30/70 to 70/30 in $15 \mathrm{~min}$ then to $90 / 10$ in $1 \mathrm{~min}$ then to $40 / 60$ in $1 \mathrm{~min}$ ).

5'-C-(1-(2-(2-(4-Methylphenoxy)ethoxy)ethyl)-4-methyl-1H-1,2,3-triazol-4-yl)-thymidine (2c). MS: $502.23\left(\left[\mathrm{M}+\mathrm{H}^{+}\right]^{+}\right), 524.22\left(\left[\mathrm{M}+\mathrm{Na}^{+}\right]^{+}\right)$. HPLC: $\mathrm{rt}=8.09 \mathrm{~min}(\mathrm{~A} / \mathrm{C}$ : from $40 / 60$ to $70 / 30$ in $10 \mathrm{~min}$ then to $90 / 10$ in $3 \mathrm{~min}$ then to $40 / 60$ in $1 \mathrm{~min})$.

(5'S)-C-(1-(Pent-3-enyl)-(4-phenoxy)-methyl)-1H-1,2,3-triazol-1-yl)-thymidine (3a). MS (ESI): 483.24 $\left(\left[\mathrm{M}+\mathrm{H}^{+}\right]^{+}\right), 506.20\left(\left[\mathrm{M}+\mathrm{Na}^{+}\right]^{+}\right)$. HPLC: $\mathrm{rt}=7.04 \mathrm{~min}(\mathrm{~A} / \mathrm{C}$ : from $30 / 70$ to $70 / 30$ in $15 \mathrm{~min}$ then to $90 / 10$ in $1 \mathrm{~min}$ then to $40 / 60$ in $1 \mathrm{~min}$ ).

5'-C-(1-Benzyl-4-methyl-1H-1,2,3-triazol-4-yl)-thymidine (3b). ${ }^{1} \mathrm{H}-\mathrm{NMR}\left(300 \mathrm{MHz}, \mathrm{DMSO} d_{6}\right), \delta_{\mathrm{ppm}}$ : $1.77\left(\mathrm{~s}, 3 \mathrm{H}, \mathrm{CH}_{3}\right.$ thymine), 2.05-2.10 (m, 2H, $\left.\mathrm{H}_{2}\right), 2.68-2.92\left(\mathrm{~m}, 2 \mathrm{H}, \mathrm{H}_{6}\right), 3.36(\mathrm{~s}, 2 \mathrm{H}, \mathrm{OH}), 3.66-3.69(\mathrm{~m}$, $\left.1 \mathrm{H}, \mathrm{H}_{4}\right), 3.82-3.95\left(\mathrm{~m}, 1 \mathrm{H}, \mathrm{H}_{5^{\prime}}\right), 4.28$ (major 0.7) and 4.41 (minor 0.3) $\left(2 \mathrm{~s}, 1 \mathrm{H}, \mathrm{H}_{3^{\prime}}\right), 5.19-5.30(\mathrm{~m}, 2 \mathrm{H}$, $\mathrm{OH}), 5.55\left(\mathrm{~s}, 2 \mathrm{H}, \mathrm{H}_{9^{\prime}}\right), 6.19-6.22\left(\mathrm{~m}, 1 \mathrm{H}, \mathrm{H}_{1^{\prime}}\right), 7.29-7.38\left(\mathrm{~m}, 5 \mathrm{H}, \mathrm{H}\right.$ phenyl), $7.64\left(\mathrm{~s}, 1 \mathrm{H}, \mathrm{H}_{8^{\prime}}\right), 7.93$ (s, $1 \mathrm{H}, \mathrm{CH}$ thymine), $11.28\left(\mathrm{~s}, 1 \mathrm{H}, \mathrm{NH}\right.$ thymine). ${ }^{13} \mathrm{C}-\mathrm{NMR}\left(75.5 \mathrm{MHz}, \mathrm{DMSO} d_{6}\right), \delta_{\mathrm{ppm}}: 12.4\left(\mathrm{CH}_{3}\right.$ thymine), $30.3\left(\mathrm{C}_{6^{\prime}}\right), 40.6\left(\mathrm{C}_{2^{\prime}}\right), 52.6\left(\mathrm{C}_{9^{\prime}}\right), 69.7\left(\mathrm{C}_{5^{\prime}}\right), 71.3\left(\mathrm{C}_{3^{\prime}}\right) 83.7\left(\mathrm{C}_{1^{\prime}}\right), 87.9\left(\mathrm{C}_{4^{\prime}}\right), 89.0\left(\mathrm{C}_{4^{\prime}}\right), 109.3$ 
(C thymine), 123.1 (C8'), 127.8 and 128.7 ( $\mathrm{CH}$ phenyl), 136.3 (C phenyl and $\mathrm{C}$ thymine), $144.2\left(\mathrm{C}_{7^{\prime}}\right)$,

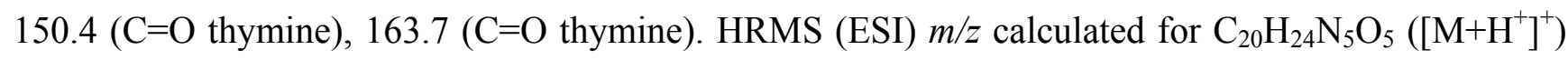
414.1771, found 414.1777. HPLC: $\mathrm{rt}=4.01 \mathrm{~min}(\mathrm{~A} / \mathrm{C}$ : from $30 / 70$ to $70 / 30$ in $15 \mathrm{~min}$ then to $90 / 10 \mathrm{in}$ $1 \mathrm{~min}$ then to $40 / 60$ in $1 \mathrm{~min})$.

\subsection{Methylation under Dilute Conditions $\left(5 \times 10^{-3} \mathrm{M}\right)$}

According to the previously described procedure [12] the monomethylstannane was prepared from Lappert's stannylene and iodomethane. To a solution of monomethylstannane $(18.0 \mathrm{mg}, 0.032 \mathrm{mmol}$, 2 equiv.) in THF $(300 \mu \mathrm{L})$ was added a commercial $1 \mathrm{M}$ solution of TBAF in THF (96 $\mu \mathrm{L}, 6$ equiv.). The colourless solution was stirred for $5 \mathrm{~min}$ and the solvent was removed under reduced pressure. The residue was solubilized in $3.2 \mathrm{~mL}$ of a DMF/DMSO 9/1 mixture, then $15 \mathrm{mg}$ of $\mathrm{Pd}_{2} \mathrm{dba}_{3}(100 \mathrm{~mol} \%)$ and $15 \mathrm{mg}$ of 4 ( $0.016 \mathrm{mmol}, 1$ equiv.) were added. The reaction mixture was stirred for $5 \mathrm{~min}$ at $100{ }^{\circ} \mathrm{C}$ under microwave conditions. The total conversion, was confirmed by analytical HPLC (Phenomenex Luna C18, $5 \mathrm{~mm}, 250 \times 4.6 \mathrm{~mm})$. After cooling, the reaction mixture was diluted with methanol and the precipitate was filtrated. Solvents were evaporated under vacuum and the crude product $\mathbf{5}$ was purified as a mixture of diastereomers by semi-preparative HPLC (Kromasil C18, $5 \mathrm{~mm}, 250 \times 20 \mathrm{~mm}$ ). MALDI-TOF: $732.1\left(\left[\mathrm{M}-\mathrm{Et}_{3} \mathrm{NH}^{+}+2 \mathrm{H}^{+}\right]^{+}\right), 754.1\left(\left[\mathrm{M}-\mathrm{Et}_{3} \mathrm{NH}^{+}+\mathrm{H}^{+}+\mathrm{Na}^{+}\right]^{+}\right)$. HPLC: $\mathrm{rt}=12.52$ and $12.98 \mathrm{~min}(\mathrm{~A} / \mathrm{B}$ : from $20 / 80$ to $30 / 70$ in $15 \mathrm{~min}$ then to $50 / 50$ in $2 \mathrm{~min}$ then to $50 / 50$ during $2 \mathrm{~min}$ then to $20 / 80$ in $2 \mathrm{~min}$ ).

\section{Conclusions}

In summary, we have demonstrated that our palladium-catalysed methyl transfer reaction could be a very fast and efficient way for the direct carbon-11 labeling of unprotected nucleosidic and oligonucleotidic substrates, even under dilute conditions. Furthermore, we are currently investigating the use of $\left[{ }^{11} \mathrm{C}\right]$-monomethylstannate, prepared according to our previous work [12] under the new coupling conditions herein developed for labelling $\mathbf{1 b}$ and $\mathbf{4}$, as well as for modified monomers $\mathbf{1 a}, \mathbf{1 b}$ and 1c incorporated into model oligonucleotide sequences $[21,22]$.

\section{Acknowledgments}

This present work was supported by the CNRS (Centre National de la Recherche Scientifique, BDI fellowship, and by a public grant from the French "Agence Nationale de la Recherche" within the context of the Investments for the Future Program, referenced ANR-10-LABX-57 named TRAIL.

\section{Conflicts of Interest}

The authors declare no conflict of interest.

\section{References}

1. Phelps, M.E.; Mazziotta, J.C.; Schelbert, H.R. Positron Emission Tomography and Autoradiography; Raven Press: New York, NY, USA, 1986; Chapter 9-11. 
2. Långström, B.; Dannals, R.F. Principles of Nuclear Medicine; W.B. Saunders: Philadelphia, PA, USA, 1995.

3. Fowler, J.S.; Wolf, A.P. Working against time: Rapid radiotracer synthesis and imaging the human brain. Acc. Chem. Res. 1997, 30, 181-188.

4. Allard, M.; Fouquet, E.; James, D.; Szlosek-Pinaud, M. State of the art in ${ }^{11} \mathrm{C}$ labelled radiotracers synthesis. Curr. Med. Chem. 2008, 15, 235-277.

5. Cai, L.; Lu, S.; Pike, V.W. Chemistry with [F-18]fluoride ion. Eur. J. Org. Chem. 2008, 2008, 2853-2873.

6. Littich, R.; Scott, P.J.H. Novel Strategies for Fluorine-18 Radiochemistry. Angew. Chem. Int. Ed. 2012, 51, 1106-1109.

7. Pretze, M.; Große-Gehling, P.; Mamat, C. Cross-coupling Reactions as valuable tool for the preparation of PET Radiotracers. Molecules 2011, 16, 1129-1165.

8. Langer, O.; Forngren, T.; Sandell, J.; Dollé, F.; Långström, B.; Någren, K.; Halldin, C. Preparation of4-[C-11] methylmetaraminol, a potential PET tracer for assessment of myocardial sympathetic innervation. J. Labelled Compd. Radiopharm. 2003, 46, 55-65.

9. Sandell, J.; Yu, M.; Edmon, P.; Garreau, L.; Chalon, S.; Någren, K.; Guilloteau, D.; Halldin, C. Synthesis, Radiolabelling and preliminary biological evaluation of radiolabeled 5-methyl-6nitroquipazine, a potential radioligand fort he serotonin transporter. Bioorg. Med. Chem. Lett. 2002, 12, 3611-3613.

10. Madsen, J.; Merachtsaki, P.; Davoodpour, P.; Bergström, M.; Andersen, K.; Thomsen, C.; Guilloteau, D.; Halldin, C. Synthesis and biological evaluation of novel carbon-11 labelled analogues of citalopram as potential radioligands fort he serotonin transporter. Bioorg. Med. Chem. 2003, 11, 3447-3456.

11. Ferrieri, R.A.; Antoni, G.; Khilberg, T.; Långström, B. Handbook of Radiopharmaceuticals. Radiochemistry and Applications; Welch, M.J., Redvanly, C.S., Eds.; Wiley: Chichester, UK, 2003; pp. 229-282.

12. Huiban, M.; Huet, A.; Barré, L.; Sobrio, F.; Fouquet, E.; Perrio, C. Methyl transfer reaction from methyliodide through modified tin reagent: A versatile method for labelling with carbon-11. Chem. Commun. 2006, 97-99.

13. Bourdier, T.; Huiban, M.; Huet, A.; Sobrio, F.; Fouquet, E.; Perrio, C.; Barré, L. Tetra- and monoorganotin reagents in palladium-mediated cross-coupling reactions for the labeling with carbon-11 of PET tracers. Synthesis 2008, 6, 978-984.

14. Herve, A.; Rodriguez, A.L.; Fouquet, E. Stille cross-coupling of activated alkyltin reagents under ligandless conditions. J. Org. Chem. 2005, 70, 1953-1956.

15. Hosoya, T.; Wakao, M.; Kondo, Y.; Doi, H.; Suzuki, M. Rapid methylation of terminal acetylenes by the Stille coupling of methyl iodide with alkynyltributylstannanes: A general protocol potentially useful fort he synthesis of short-lived $\left(\mathrm{CH}_{3}\right)$-C-11-labeled PET tracers with a 1-propynyl group. Org. Biomol. Chem. 2004, 2, 24-27.

16. James, D.; Escudier, J.-M.; Amigues, E.; Schulz, J.; Vitry, C.; Bordenave, T.; Szlosek-Pinaud, M.; Fouquet, E. A 'click-chemistry' approach to the efficient synthesis of modified nucleosides and oligonucleotides for PET imaging. Tetrahedron Lett. 2010, 51, 1230-1232. 
17. Harris, D.H.; Lappert, M.F. Monomeric, volatile bivalent amides of group-IVB elements, $\mathrm{M}(\mathrm{NR} 12)_{2}$ and $\mathrm{M}(\mathrm{NR} 12)_{2}\left(\mathrm{M}=\mathrm{Ge}, \mathrm{Sn}\right.$ or $\left.\mathrm{Pb}-\mathrm{R} 1=\mathrm{Me}_{3} \mathrm{Si}, \mathrm{R} 2=\mathrm{Me}_{3} \mathrm{C}\right)$. J. Chem. Soc. Chem. Commun. 1974, 895-896.

18. Schaeffer, C.D.; Zuckerman, J.J. Tin(II)organosilylamines. J. Am. Chem. Soc. 1974, 96, 7160-7162.

19. Banuls,V.; Escudier, J.-M.; Zedde, C.; Claparols, C.; Donnadieu, B.; Plaisancié, H. Stereoselective synthesis of (5'S)-5'C-(5-bromo-2-penten-1-yl)-2'-deoxyribofuranosyl thymine, a new convertible nucleoside. Eur. J. Org. Chem. 2001, 4693-4700.

20. Escudier, J.-M.; Dupouy, C.; Fountain, M.A.; del Mundo, I.M.A.; Jacklin, E.M.; Morrow, J.R. Synthesis and luminescence properties of a trinucleotide-europium(III) complex conjugate. Org. Biomol. Chem. 2009, 7, 3251-3257.

21. Omuni, A.; Beach, D.G.; Baker, M.; Gabryelski, W.; Manderville, R.A. Postsynthetic guanine arylation of DNA by Suzuki-Miyaura cross-coupling. J. Am. Chem. Soc. 2011, 133, 42-50.

22. Wicke L.; Engels, J.W. Postsynthetic on column RNA labelling via Stille coupling. Bioconjugate Chem. 2012, 23, 627-642.

Sample Availability: Samples of materials, analytical procedures, characterization data of $\mathbf{2 a}-\mathbf{c}, \mathbf{3 a}-\mathbf{b}$, $\mathbf{4}$ and $\mathbf{5}$ are available from the author.

(C) 2013 by the authors; licensee MDPI, Basel, Switzerland. This article is an open access article distributed under the terms and conditions of the Creative Commons Attribution license (http://creativecommons.org/licenses/by/3.0/). 